\title{
External sulfate attack in dam concretes with thaumasite formation
}

\author{
S. Chinchón-Payáa $\bowtie$, A. Aguado ${ }^{\mathrm{b}}$, H.W. Nugteren ${ }^{\mathrm{c}}$, S. Chinchón $^{\mathrm{a}}$ \\ a. Universidad de Alicante, (Alicante, Spain) \\ b. Universidad Politécnica de Cataluña, BarcelonaTech, (Barcelona, Spain) \\ c. Delft University of Technology, (Delft, The Netherlands) \\ 冈s.chinchon@ua.es
}

\author{
Received 4 December 2013 \\ Accepted 22 May 2014 \\ Available on line 26 J anuary 2015
}

\begin{abstract}
Concrete core samples extracted from different areas of the Mequinenza Dam (Spain) have been studied and expansive reactions affecting the structure were not found. However, expansive reactions in the concrete of certain parts located near the abutments of two galleries have been observed as a consequence of an external sulfate attack due to the sulfur compounds contained in the lignites that are present on the surrounding terrain. Secondary gypsum, ettringite, and thaumasite, as well as several sulfate efflorescence have been detected. The thaumasite formed in the degraded concrete is related to a Thaumasite Sulfate Attack (TSA). Scanning Electron Microscopy (SEM) and Rietveld analyses of the TSA samples would show that thaumasite could have been formed thanks to ettringite acting as nuclei or by a direct precipitation from solutions within the pores of the cement matrix.
\end{abstract}

KEYWORDS: Concrete dam; Sulfate attack; Thaumasite

Citation/Citar como: Chinchón-Payá, S.; Aguado, A.; Nugteren, H.W.; Chinchón, S. (2015) External sulfate attack in dam concretes with thaumasite formation. Mater. Construcc. 65 [317], e042 http://dx.doi.org/10.3989/mc.2015.10513.

RESUMEN: Ataque sulfático externo en hormigones de presa con formación de thaumasita. Se han estudiado testigos de hormigón extraídos de diferentes zonas de la presa de Mequinenza (España) descartando la existencia de una reacción expansiva que pudiera afectar a la estructura. Sin embargo, se han observado reacciones expansivas en el hormigón de ciertas zonas próximas a los estribos de dos galerías, como consecuencia de un ataque sulfático externo debido a los compuestos de azufre contenidos en los lignitos que están presentes en los terrenos circundantes. Se ha identificado un conjunto de productos relacionados con el ataque sulfático: yeso secundario, ettringita y thaumasita, además de sales sulfatadas solubles. Las zonas más degradadas del hormigón coinciden con una cristalización abundante de thaumasita (Thaumasite Sulfate Attack-TSA-). El estudio de las muestras de TSA, mediante microscopía electrónica de barrido (SEM) y el método de Rietveld, indicaría que la thaumasita podría haberse formado a partir de la ettringita como medio de nucleación o por precipitación directa a partir de sus componentes en disolución dentro de los poros de la matriz cementicia.

PALABRAS CLAVE: Hormigón de presa; Ataque sulfático; Thaumasita

Copyright: (C) 2015 CSIC. This is an open-access article distributed under the terms of the Creative Commons Attribution-Non Commercial (by-nc) Spain 3.0 License.

\section{INTRODUCTION}

Sulfate attack on concrete is a widely-studied and well-documented type of degradation (1-3). Sulfate ions can originate from two different sources.
If sulfates are dissolved in water with which the structure is in contact, their origin is external and therefore provoke the so-called external sulfate attack (ESA); on the other hand, if sulfates are present in the concrete itself, then this is called an 
internal sulfate attack (ISA) (4). This internal presence of sulfates can occur when the concrete has an excess of gypsum used as a setting retardant in the cement hydration process or when aggregates containing gypsum, iron sulfides or other salts with sulfates, are used.

In general, sulfate attack comprises a set of reactions that have sulfate ions in common. Despite that the stages involved, the reactive phases, and the reaction products have been well documented in laboratory experiments, to many engineers the term sulfate attack is reserved to the cases where those processes have affected the concrete structure durability and strength $(4,5)$.

The two most outstanding reactions taking place because of sulfates are: (a) the formation of gypsum $\left(\mathrm{CaSO}_{4} \cdot 2 \mathrm{H}_{2} \mathrm{O}\right)$ due to the reaction between sulfates and portlandite; and (b) the formation of secondary strongly-expansive ettringite $\left(3 \mathrm{CaO} \cdot \mathrm{Al}_{2} \mathrm{O}_{3} \cdot 3 \mathrm{CaSO}_{4} \cdot 32 \mathrm{H}_{2} \mathrm{O}\right)$. This last reaction occurs between aluminate hydrates and sulfate anions or through the reaction of aluminate hydrates with the gypsum formed during the first reaction (6).

Secondary ettringite and gypsum formation damages the concrete due to internal stresses which cause expansion. Some studies focus on the impact of newly-formed gypsum, and Tian and Cohen (2000) conclude in their study that gypsum formation - either through a topochemical reaction or through a reaction of components in solution - can cause significant expansion (7). Another study by Santhanam et al., (2003) also assumes expansion in $\mathrm{C}_{3} \mathrm{~S}\left(3 \mathrm{CaO} . \mathrm{SiO}_{2}\right)$ and $\mathrm{PC}$ (Portland cement) mortars due to gypsum formation (8). The crystallisation of secondary ettringite is much more harmful than that of newly-formed gypsum $(9,10)$ and has been studied extensively, most probably because it is ettringite that damages the structure to a greater extent (11-13). The most usual measure adopted to prevent the formation of secondary ettringite is the utilisation of cements with a low aluminate content or high blast furnace slag content, that is, the so-called sulfur resistant cements.

In addition to newly-formed gypsum and ettringite, another product is formed under certain circumstances as a result of sulfate attack: thaumasite $\left(\mathrm{CaSiO}_{3} \cdot \mathrm{CaCO}_{3} \cdot \mathrm{CaSO}_{4} \cdot 15 \mathrm{H}_{2} \mathrm{O}\right)$. However, this product does not arise from a reaction involving the aluminates in the cements that make up the concrete and could therefore appear in a concrete where sulfur resistant cement has already been used. Rather than the expansive power of the thaumasite in the cement matrix, the most harmful aspect about the appearance of thaumasite is the fact that it is formed through a reaction of sulfates and the calcium silicate hydrates $(\mathrm{C}-\mathrm{S}-\mathrm{H})$, which means that concrete loses its main cementing phase and consequently becomes a mass without any consistence that becomes degraded or crumbles under the slightest pressure.
The appearance of thaumasite in structures affected by sulfate attack has been documented by numerous researchers in recent years (14-19). These authors provide cases of thaumasite formation in structures, buildings and various cement materials in many places. There have also been cases of dams or facilities attached to them, in which thaumasite has been detected, though the examples are scarce $(20,21)$. Some authors draw a distinction in the appearance of thaumasite between Thaumasite Formation (TF) and Thaumasite Sulfate Attack (TSA) seeking to distinguish the appearance of thaumasite at levels where it is harmless (TF), because its amount is small and occupies the pores of the concrete, from the massive thaumasite crystallisation, which is harmful indeed (TSA) $(22,23)$.

There exists some controversy on the formation of thaumasite and its possible relation with ettringite. Three theories can be distinguished: (1) Direct precipitation from solutions within the pores of the cement matrix. (2) Transformation or conversion of ettringite by replacement of aluminum with silicon in a solid solution. (3) Precipitation of thaumasite on ettringite crystals, whereby the ettringite crystals act as nuclei $(18,24)$.

The present paper shows the study of expansive reactions that occur in certain parts of Mequinenza dam (Spain), in some cases with massive presence of thaumasite, although this does not pose a structural problem. The dam was built in a closed valley formed by chemical sediments composed of alternating limestone and gypsum deposits. Intercalated are significant lignite layers (25). For the first time, we have established a relationship between deteriorated concrete and the presence of high sulfur lignites.

The application of Rietveld and SEM analyses allowed us to perform a crystallographic study of the thaumasite in order to formulate a hypothesis about its origin and relationship with ettringite.

\section{MATERIALS AND METHODS}

\subsection{The Mequinenza dam}

The dam at Mequinenza is a gravity dam located in the municipality of the same name, in the province of Zaragoza (Spain), and is located in the Ebro River (Figure 1a). The maximum dam height is $79 \mathrm{~m}$ and its crest length is $461 \mathrm{~m}$. The total dam body volume is $1.1 \times 10^{6} \mathrm{~m}^{3}$. The valley profile is open (U-type). Figure $1 \mathrm{~b}$ shows a view of the dam from the face downstream.

The reservoir was first filled in December 1965, although its level was later lowered and filled again in 1969. A whole series of complementary works were carried out during that period in order to respond to a growing demand for safety after the breaches suffered by the dams located at Vega de 

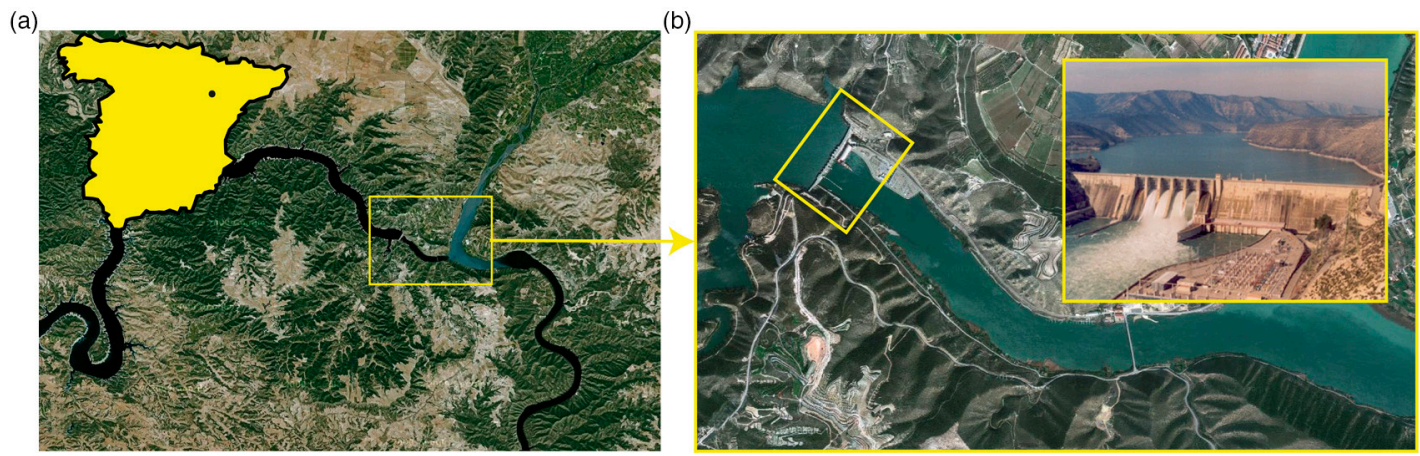

Figure 1. (a) Location of Mequinenza dam and reservoir. (b) Downstream face of the dam.

Tera (Spain) in 1957, Malpasset (France) in 1959 and Vajont (Italy) in 1963, and before the emerging doubts about the behaviour of the foundations, formed by horizontal limestone strata separated by thin lignite sheets (26).

\subsection{Geological settings}

The Mequinenza dam and its surroundings are located in the Bajo Cinca region on the southern tip of a large geological unit: the Ebro River Basin. Figure 2 shows sheet 415 of the Geological Map of Spain on a scale of 1:50.000 (27) where the tertiary Oligocene deposits on which the dam stands, as well as the large quantities of lignites (black dot plus Lig text in Figure 2) repeatedly mentioned in this paper, can be seen among the rest of the geological formations.

The Mequinenza dam was built upon materials in which chemical sediments (limestones and gypsum) are predominant over detrital ones. As it happens in most of the Ebro Basin (except the strips near the ranges that surround it), the strata from the Tertiary period remain practically horizontal, just as they were deposited (Figure 3a).
The aforementioned carbonate domains of these units include the coal layers in the Mequinenza mining district. These are groups of small layers with low thickness $(20-80 \mathrm{~cm})$ characterised by their subhorizontal position and great continuity, which have come to be known as Benzol in the mining context (Figure 3.b). There are still many exploration and research permits in force, although few active extractions take place and none of them in this particular area (29).

The lignites at Mequinenza are high-sulfurcontent coals. Olivella (2000) reported an average sulfur content of $13.35 \%$ (expressed as total sulfur) in Mequinenza samples (30), similar to the $13.6 \%$ found by White et al. (1994) (31). In an more recent paper Fulloa (2007) presents dry-sample sulfur contents for lignites ranging from $7.6 \%$ to $11.4 \%$ (32).

\subsection{Materials}

Concrete core samples were extracted from all concrete blocks and auxiliary elements of the dam. Specifically, 19 concrete core samples of $9 \mathrm{~cm}$ of diameter and an average length between 30 and $40 \mathrm{~cm}$ were analysed.
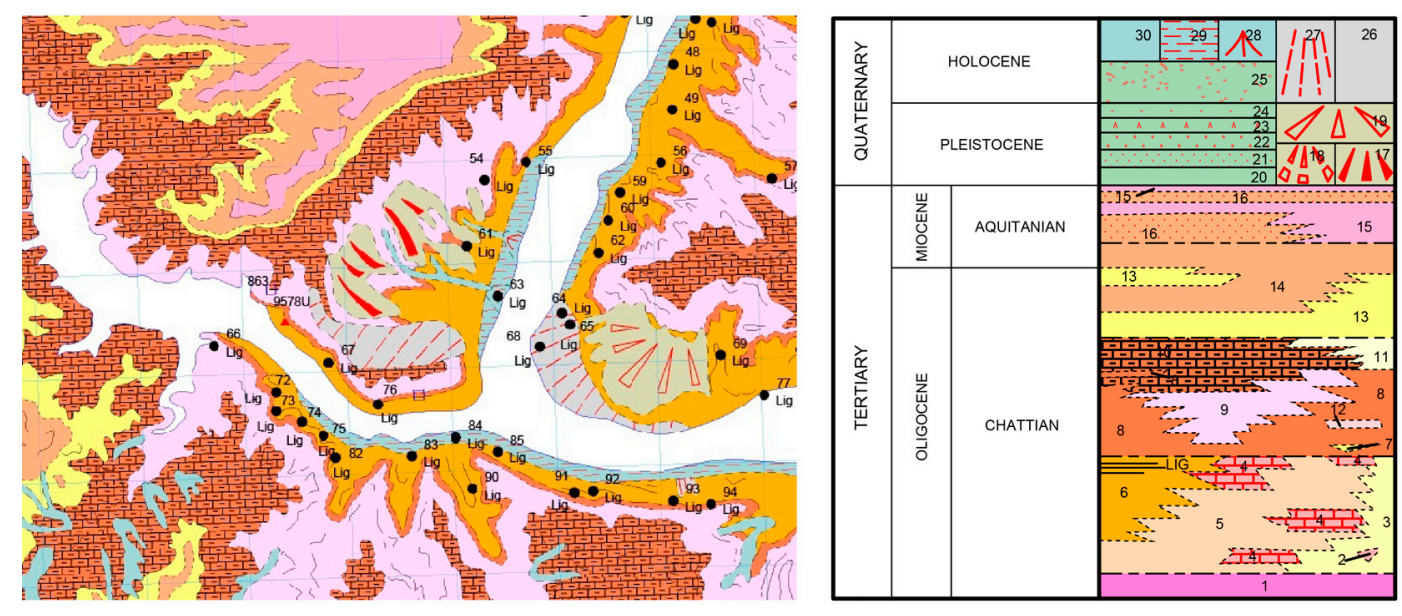

FIGURE 2. Geological sheet of Mequinenza (27). 
(a)

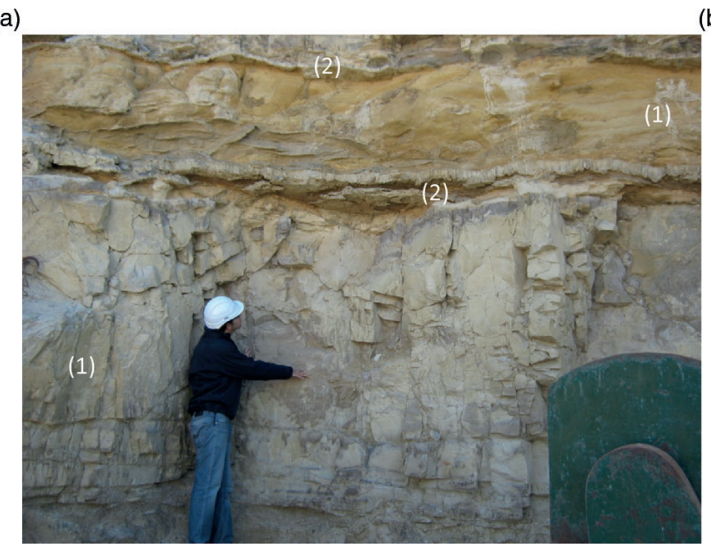

(b)

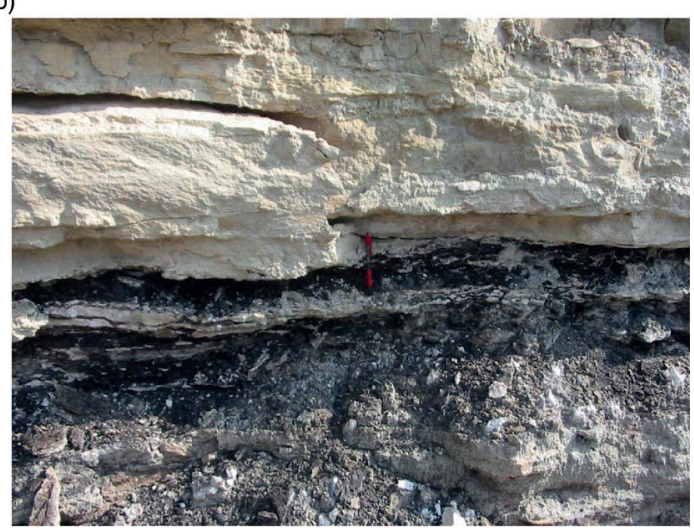

Figure 3. (a) Alternation of limestones (1) and gypsum (2) in the left hillside of the dam. (b) Lignite horizons near the Boquereta, municipal area of Mequinenza (28).

Concrete as well as efflorescence samples were also collected from the most highly degraded galleries. These galleries are Gallery $22 \mathrm{~m}$ and Gallery $81 \mathrm{~m}$ located in an area of the abutments in contact with the terrain where lignites emerge.

Aggregates from the gravel and from the surroundings of the dam and lignites from the old mine were collected.

\subsection{Analyses}

First examinations were conducted by an Optical Microscope Nikon SMZ-10A to inspect the concrete core samples and easily locate the signs of degradation.

A Hitachi S3000N Scanning Electron Microscope with a Bruker XFlash 3001 X-ray detector to Energy-dispersive X-ray spectroscopy (SEM-EDX) was used for the chemical and morphological characterization of the efflorescences and degraded concrete samples. Mappings of elemental distribution in the surface of the sample are shown when necessary.

X-ray diffraction (XRD) spectra were obtained in a Bruker machine using $\mathrm{Cu} \mathrm{K} \alpha$ radiation with a graphite monochromator and a $\mathrm{NaI}(\mathrm{Tl})$ scintillation detector. 4 to $60^{\circ} 2 \theta$ scanning was carried out at a speed of $1 \%$ minute (step of $0.05^{\circ} 2 \theta$ and 3 seconds per step). A refinement of the XRD spectrum of a sample containing thaumasite was performed using the Rietveld method $(33,34)$ in order to accurately determine the thaumasite cell parameters and estimate the amounts in the crystalline phases identified (35). In this case 4 to $80^{\circ} 2 \theta$ scanning was carried out with step size of $0.017^{\circ} 2 \theta$ and a measuring time of 50 seconds per step.

$\mathrm{X}$-ray Fluorescence analysis (XRF) was conducted with the equipment Philips Magix Pro equipped with a rhodium tube and beryllium window to the elemental analysis of some alteration compounds.

\section{RESULTS AND DISCUSSION}

\subsection{Concrete core samples}

Examination of aggregates from the dam concretes revealed that it was composed of rounded off gravel (Figure 4a). As common in civil construction, this gravel was extracted from the surrounding area, in this case the Lower Pleistocene terraces (29). Figure $4 \mathrm{~b}$ shows the XRD spectrum representative of almost all of the aggregates, of limestone nature, and similar to the gravel composition of the Pleistocene terraces.

The dam was completed in 1964 and there is no precise reference to the type of cement used in the concrete manufacture. However, some of the reports made in 1969 speak of the "cement would be the type P-350-Y" which would correspond to a current CEM I 32,5 N-SR 5. There is no mention in the Dam Book to the organic additives that could have been used.

The concrete core samples were stained with Poole and Thomas method (36) to verify or rule out the presence of aggregates containing gypsum or other sulfur compounds. Neither sulfides nor gypsum have been found by using this method and, together with the limestone nature of aggregates, rules out the possibility of an internal sulfate attack in concrete.

Most of the concrete core samples did not show any sign of degradation except some rims in aggregates and white gel, both typical signs of an Alkali Aggregate Reaction (ARR). Few samples analysed by means of SEM-EDX showed AAR gel as well as secondary ettringite filling the concrete pores. However, these degradation products are not fully 
(a)

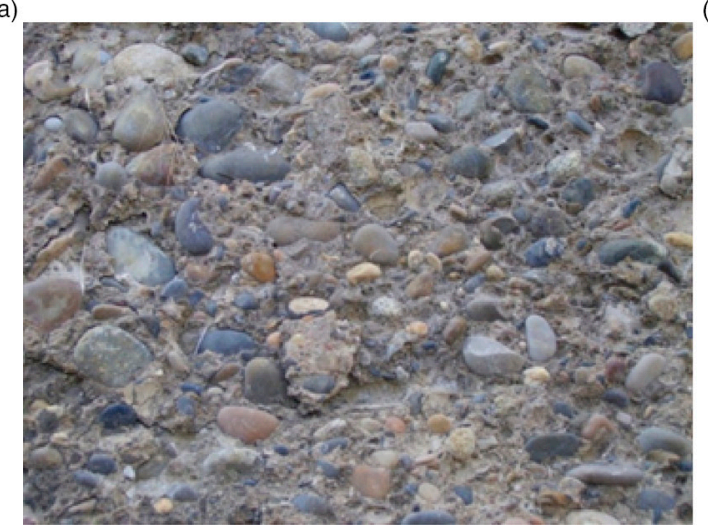

(b)

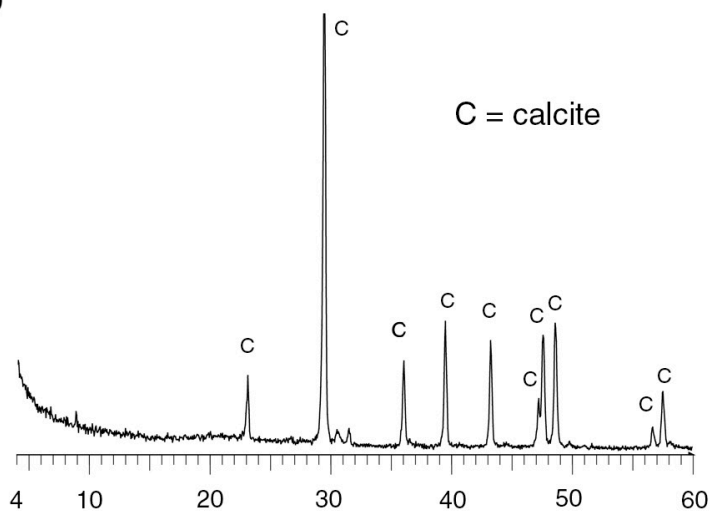

FIgURE 4. (a) Aspect of aggregates of a concrete sample coming from a downstream face and (b) XRD spectrum. The aggregates contain more than $95 \%$ calcite.

extended in the concrete matrix and are located in a few pores.

Our data are consistent with those from a private report 1978 from which we extract a paragraph: "(...) The Instituto Torroja presents its report according to which there has been no attack to the concrete by ion $\mathrm{SO}^{2-}$, nor expansion due to the chemical composition of aggregates or cement (...)".

\subsection{Superficial concrete and efflorescence samples from Galleries $22 \mathrm{~m}$ and $81 \mathrm{~m}$}

Both ends of the gallery $22 \mathrm{~m}$ communicate with the abutments and the materials of the surroundings. Lignite layers are present in the rocks of the abutments. The state of the concrete in the gallery shows evident degradation signs.

Figure 5a shows the appearance of the rock and lignite which are present in the walls at the gallery $22 \mathrm{~m}$. Figure $5 \mathrm{~b}$ shows part of the wall and the ceiling of gallery $22 \mathrm{~m}$ near the zone seen in Figure 5a, which contained not only calcite stalactites resulting from portlandite carbonation but also stalactites with ochre tones. XRF analysis showed that those were composed of native sulfur.

Whitish efflorescences appeared on the walls of gallery $22 \mathrm{~m}$ (Figure 6a). The analyses by SEMEDX of these solids show that they are composed of calcium and potassium sulfates (Figure 6b). The superficial concrete is completely carbonated and it also contains considerable amounts of gypsum and thaumasite (Figure 6c).

The alteration of lignites in the course of weathering causes important physical changes such as expansion and fracture, largely due to the formation of sulfate hydrates. On the other hand, those sulfates react with cement paste aluminates of the dam concrete that are in contact, generating expansive compounds of ettringite and thaumasite-type minerals. Such processes become particularly relevant in the case of Mequinenza, where the sulfur content in lignites is very high. (a)

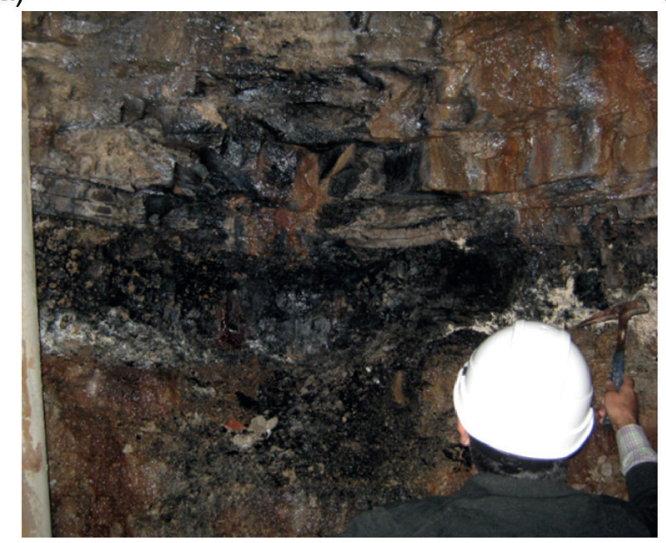

(b)

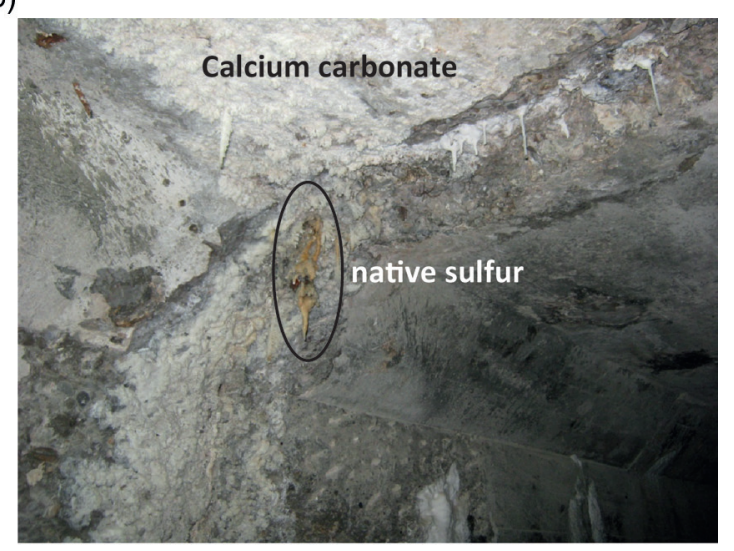

FIGURE 5. (a) Lignite horizons in the rock present in the abutment at the gallery $22 \mathrm{~m}$ level. (b) Part of the wall and the ceiling of gallery 22. 
(a)

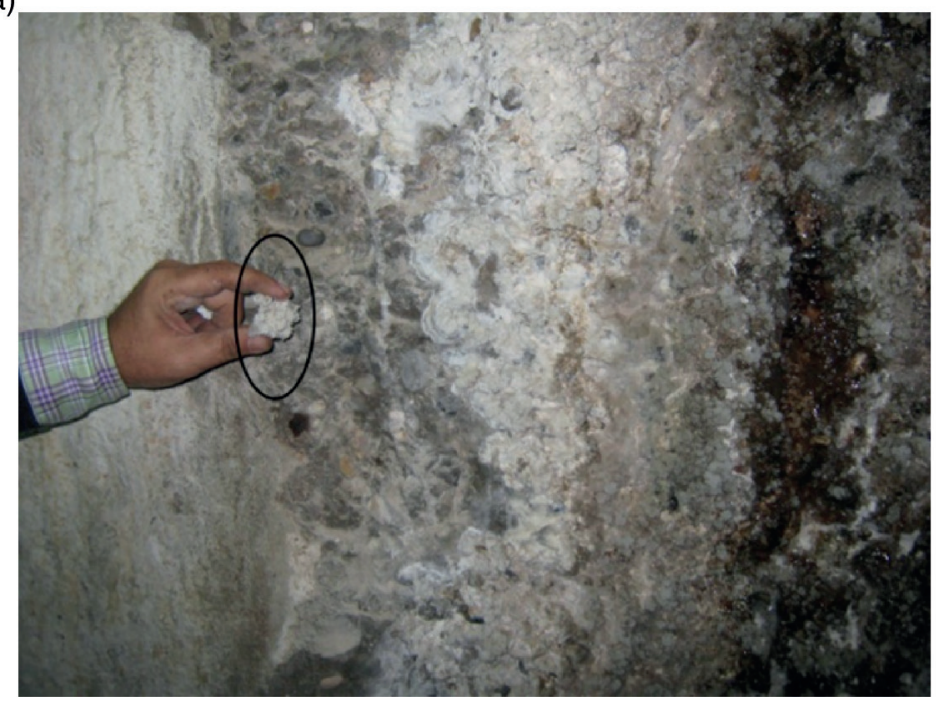

(b)

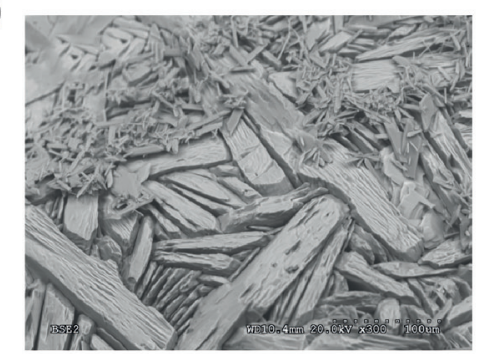

(c)

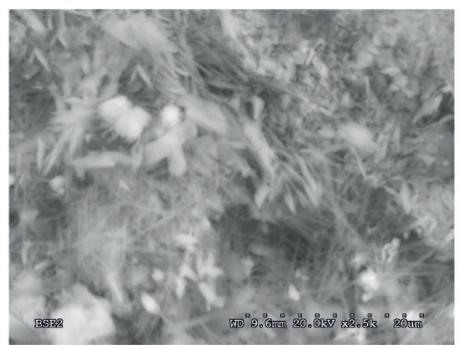

FiguRE 6. (a) Wall in the gallery at the $22 \mathrm{~m}$ level. The marked zone corresponds to the whitish solid products. These products are analysed by SEM and two zones or types were detected: (b) K and Ca sulfates; (c) gypsum, calcite and thaumasite.

Gallery $81 \mathrm{~m}$ provided access to an old mine located in the left abutment where some efflorescences which covered the whole trench wall turned out to be thenardite $\left(\mathrm{Na}_{2} \mathrm{SO}_{4}\right)$ (Figure 7$)$ a very common sulfate compound in all coal tailings since all lignites have varying amounts of $\mathrm{Na}$. The presence of quartz in the XRD spectrum is justified since it is the inert mineral found in greatest proportion in all lignite.

The water that runs through gallery $81 \mathrm{~m}$ in areas where it seeped through the lignites, which comes from the abutment, has a clearly reddish tint (Figure 8a). A sample of brown mud was taken and after drying was analyzed by XRD. Only a small amount of calcite on a high background was observed in the spectrum, usual when the sample contains large amounts of $\mathrm{Fe}$ and it is analysed with $\mathrm{Cu}$ anti-cathode. The analysis by XRF yields a Fe content of $21 \%$.
This colour may be attributed to iron hydroxides resulting from the weathering of pyrite in the lignites.

\subsection{Thaumasite Sulfate Attack (TSA)}

Gallery 81 shows evident signs of a severe concrete degradation in the chutes through which the filtered water flows in the gallery and, to a lesser extent, in the walls (Figure 8b and c) in a situation similar to that reported by Ma, B in 2006 (21). The sulfate concentration in that water, analyzed by atomic absorption, is $1528 \mathrm{ppm}$.

More specifically, at least the 5 first centimetres of concrete in the chute crumbles in the hand. In this zone samples were extracted every 2 meters and the analysis of the concrete shows that degradation is caused by a sulfate attack in which thaumasite has (a)

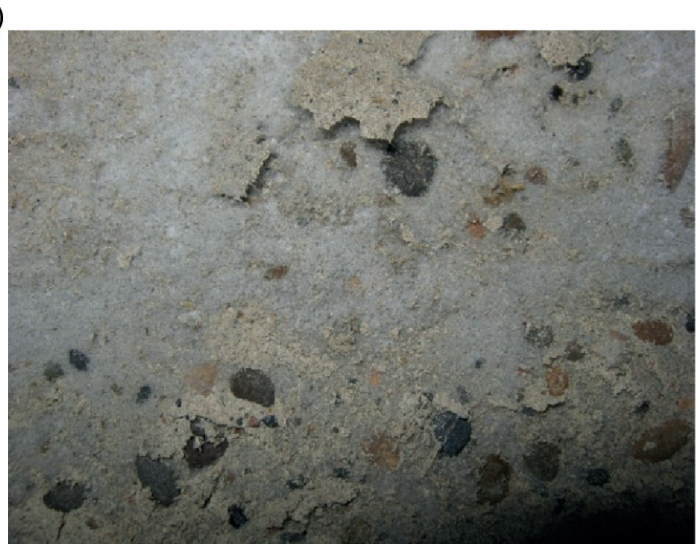

(b)

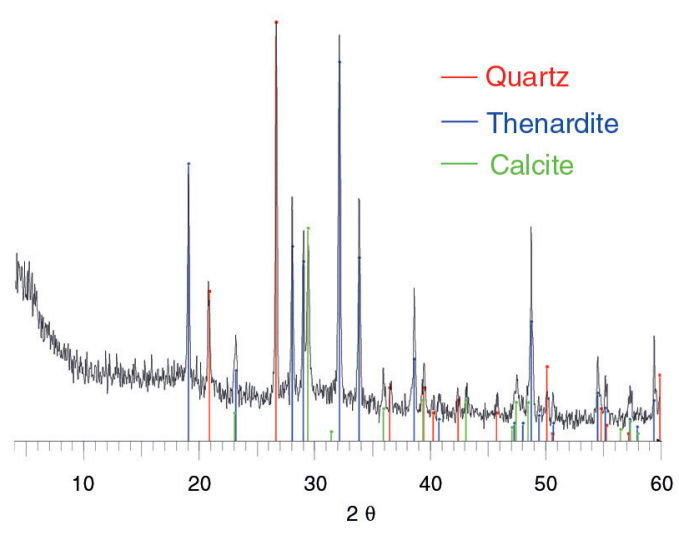

Figure 7. (a) Aspect of the acicular soluble crystals on the wall in gallery 81 close to the old mine and (b) XRD analysis shows thenardite to be present. 
(a)

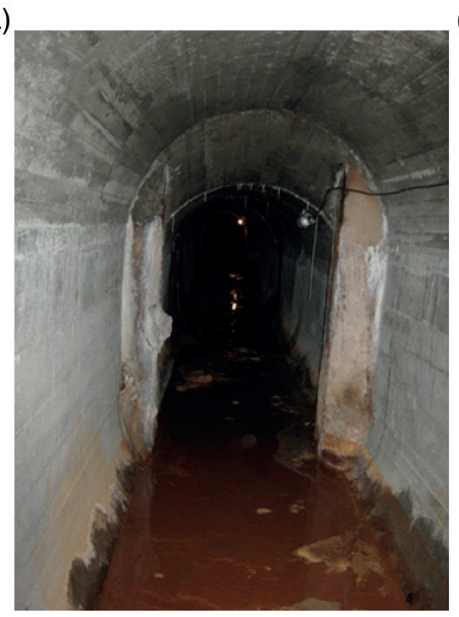

(b)

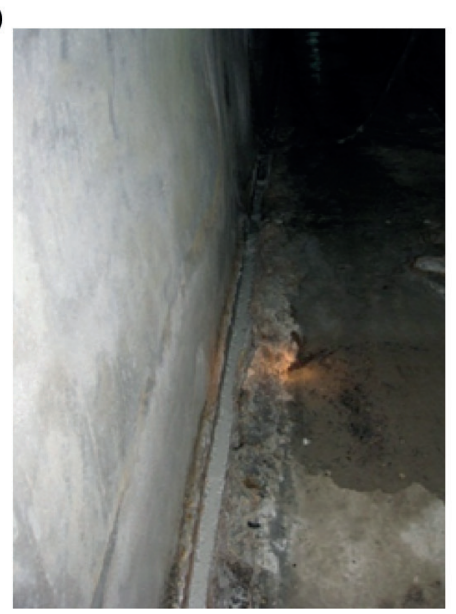

(c)

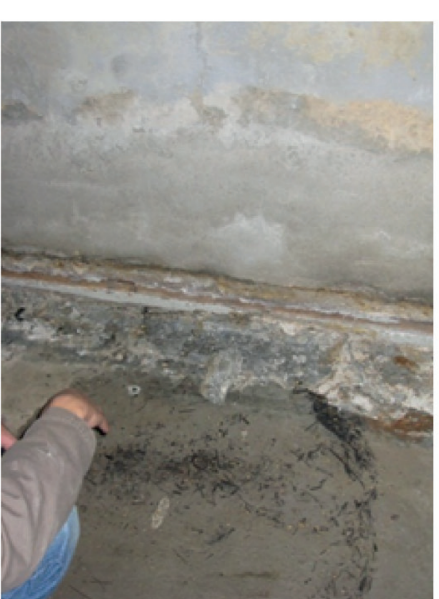

Figure 8. (a) Brownish waters in the floor of gallery $81 \mathrm{~m}$. (b) and (c) Photos of the wall and chute where water is flowing in gallery $81 \mathrm{~m}(25)$.

been formed (Thaumasite Sulfate Attack -TSA-). Figure 9a shows the morphology and composition of a representative sample analysed by SEM-EDX.

A sample of about $1 \mathrm{~kg}$ weight of the altered zone of the chute was quartered and analyzed by XRD. Figure 9b shows the XRD analysis where phases identified were calcite and quartz as well as thaumasite, gypsum and bassanite $\left(2 \mathrm{CaSO}_{4} \cdot \mathrm{H}_{2} \mathrm{O}\right)$. These three last compounds are products of a sulfate attack. In order to know the amount of thaumasite and get information about its structure, the XRD analysis was repeated by varying the experimental conditions as stated in the third paragraph of section 2.4 and analyzed by the Rietveld method.

Rietveld refinements have been performed considering the 5 identified phases of sample by means of FullProf software (37). The global refined parameters were the zero displacement parameters and six coefficients of the polynomial considered background. The phase dependent refined parameters were the scale factors, the cell parameters and the profile shape parameters.

The Rietveld analysis of the sample accurately determines the thaumasite cell parameters and cell volume: $a=11.0685$ (19) $\AA, c=10.4309$ (37) $\AA$ and $V=1106.70$ (38) $\AA^{3}$ (Hexagonal spacial group $\mathrm{P} 63, \mathrm{Z}=2$ ). The analysis also provides the concentrations of the phases considered (Table 1).

The lattice parameters would correspond to a thaumasite-ettringite solid solution compound (woodfordite) according to a first study of Barnett, S. J (38), but they are found almost within the miscibility gap according to what they expressed in a second work (39). In our case, the huge quantity of thaumasite formed contradicts the hypothesis of thaumasite being formed via the woodfordite route. The amount of thaumasite found in the chute sample cannot be explained by the substitution of $\mathrm{Si}$ for the $\mathrm{Al}$ of ettringite, simply because no concrete has such a large quantity of ettringite. Figure 10 (a)

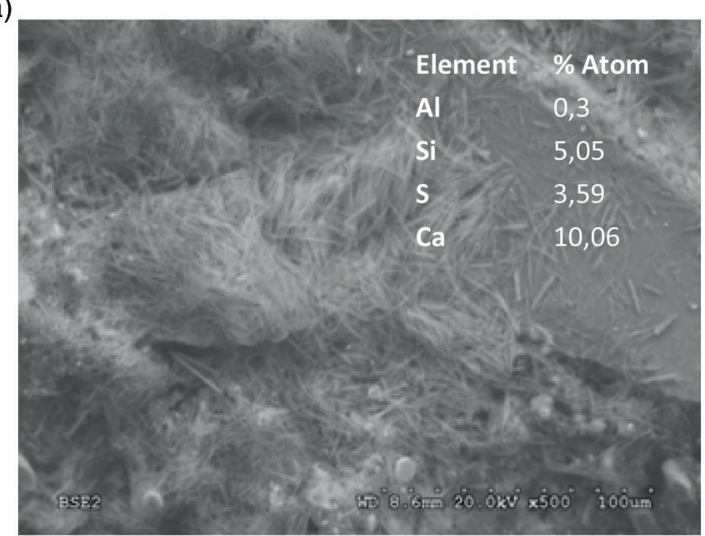

(b)

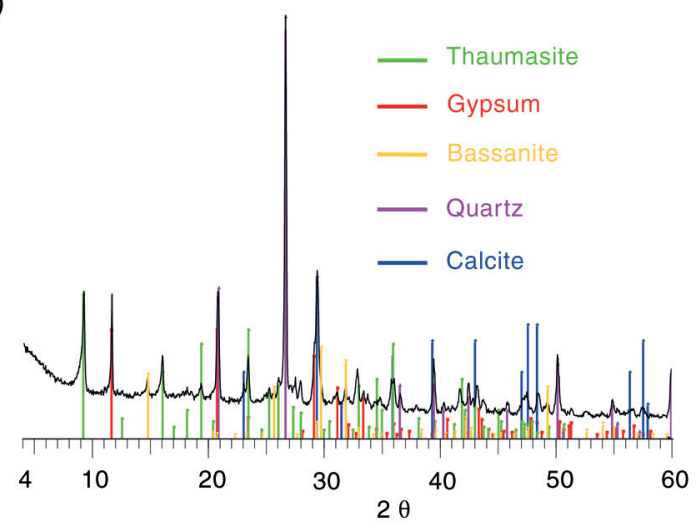

FIGURE 9. (a) SEM-EDX analysis of a concrete sample obtained in the zone of Figure $8 \mathrm{~b}$ and c. Atomic percentage of Al, Si, S and $\mathrm{Ca}$ are shown. (b) XRD analysis. Phases identified were thaumasite, gypsum, bassanite, calcite and quartz. 
TABLE 1. Quantification of the phases considered in the Rietveld analysis

\begin{tabular}{lccccc}
\hline Phase & Quartz & Thaumasite & Calcite & Bassanite & Gypsum \\
\hline Concentration & $38.5(1.5) \%$ & $30.6(2.2) \%$ & $22.8(1.6) \%$ & $5.0(0.6) \%$ & $3.1(0.3) \%$ \\
\hline
\end{tabular}

(a)

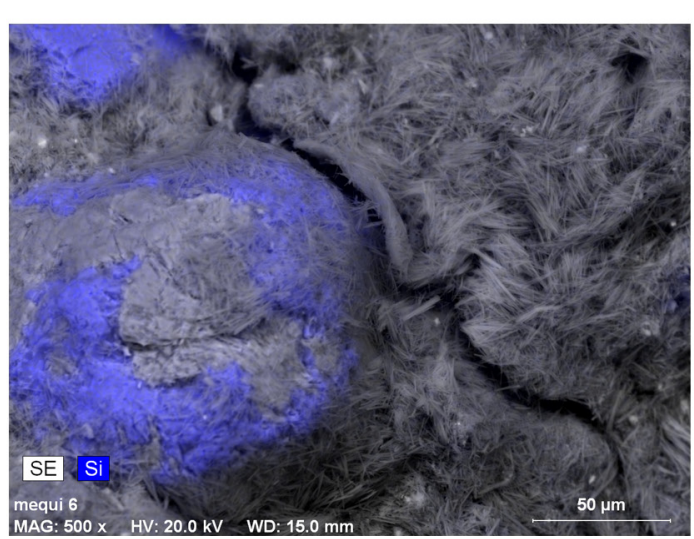

(b)

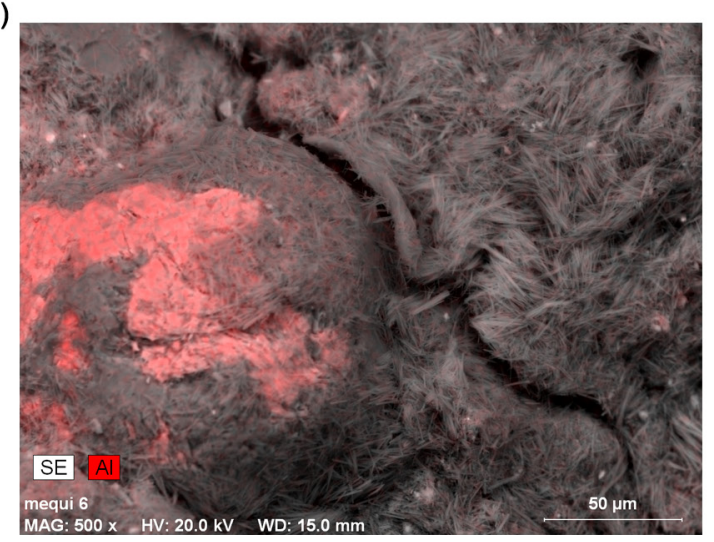

FIGURE 10. The images obtained by means of SEM-EDX show the elemental distribution for Si (a) and $\mathrm{Al}$ (b) in the surface of a sample degraded by a TSA.

shows the mappings for $\mathrm{Si}$ and $\mathrm{Al}$ in una porción the sample where Rietveld analysis was conducted. Those elements are located in different places, which would correspond to a sample formed by ettringite and thaumasite separately and not a by solid solution compound of both.

It seems reasonable to us that the formation mechanism of thaumasite would agree with one of the possibilities of thaumasite formation stated by Crammond (22) where thaumasite uses ettringite as germen for its initial nucleation.

\section{CONCLUSIONS}

The Mequinenza dam concretes are made with rolling aggregates which mostly have a carbonatic nature. No iron sulfides or other sulfur compounds appeared in those materials, reason why an internal sulfate attack can be ruled out. No expansive reaction affecting the structure is observed.

However, expansive reactions in the concrete of certain parts located near the abutments of two galleries have been observed as a consequence of an external sulfate attack due to the sulfur compounds contained in the lignites that are present on the surrounding terrain.

As other authors have already documented, the highest degradation of concrete occurs in areas which have been in permanent contact with water, more specifically in the chutes that act as drains in one of the galleries and in the walls where water seepage appear. A large part of the concrete in those chutes has become a mass without any cohesion during a sulfate attack process leading to thaumasite formation (TSA).
SEM and Rietveld analyses of a TSA samples shows that thaumasite could have been formed thanks to ettringite acting as nuclei or by a direct precipitation from solutions within the pores of the cement matrix.

\section{ACKNOWLEDGEMENTS}

The authors wish to show their gratitude for the economic support received from Ministerio de Economía y Competitividad (Spain) through the Research Project BIA2010-20913-C02-02 (PREDICEX) and BIA2011-28798-C02-02 "La reacción sulfática interna entre áridos con distintos compuestos de azufre y cementos de diferente contenido de aluminatos".

We also thank Juan M: Buil, José F. Conesa, M. Chacón y Felipe Río (ENDESA), for their continued support over the years in the study of concrete dams with expansions.

\section{REFERENCES}

1. Ayora, C.; Chinchón, S.; Aguado, A.; Guirado, F. (1998) Weathering of iron sulfides and concrete alteration: thermodynamic model and observation in dams from Central Pyrenees, Spain, Cem. Concr. Res. 28 [9], 1223-1235. http:// dx.doi.org/10.1016/S0008-8846(98)00137-9.

2. Chinchón, J.S.; Ayora, C.; Aguado, A.; Guirado, F. (1995) Influence of weathering of iron sulfides contained in aggregates on concrete durability, Cem. Concr. Res. 25 [6], 1264 1272. http://dx.doi.org/10.1016/0008-8846(95)00119-W.

3. Casanova, I.; Agullo, L.; Aguado, A. (1996) Aggregate expansivity due to sulfide oxidation. 1. Reaction system and rate model, Cem. Concr. Res. 26 [7], 993-998. http:// dx.doi.org/10.1016/0008-8846(96)00085-3.

4. Collepardi, M. (2003) A state-of-the-art review on delayed ettringite attack on concrete, Cem. Concr. Comp. 25 [4-5], 401-407. http://dx.doi.org/10.1016/S0958-9465(02)00080-X. 
5. Neville, A. (2004) The confused world of sulfate attack on concrete, Cem. Concr. Res. 34 [8], 1275-1296. http://dx.doi. org/10.1016/j.cemconres.2004.04.004.

6. Taylor, H.F.W. (1997) Cement chemistry: Thomas Telford. http://dx.doi.org/10.1680/cc.25929.

7. Tian, B.; Cohen, M.D. (2000) Does gypsum formation during sulfate attack on concrete lead to expansion?, Cem. Concr. Res. 30 [1], 117-123. http://dx.doi. org/10.1016/S0008-8846(99)00211-2.

8. Santhanam, M.; Cohen, M.D.; Olek, J. (2003) Effects of gypsum formation on the performance of cement mortars during external sulfate attack, Cem. Concr. Res. 33 [3], 325332. http://dx.doi.org/10.1016/S0008-8846(02)00955-9.

9. Chen, J.-K.; Jiang, M.-Q. (2009) Long-term evolution of delayed ettringite and gypsum in Portland cement mortars under sulfate erosion, Constr. Build. Mater. 23 [2], 812-816. http://dx.doi.org/10.1016/j.conbuildmat.2008.03.002.

10. Lee, H.; Cody, R.; Cody, A.; Spry, P. (2005) The formation and role of ettringite in Iowa highway concrete deterioration, Cem. Concr. Res. 35 [2], 332-343. http://dx.doi.org/10.1016/j. cemconres.2004.05.029.

11. Diamond, S. (1996) Delayed ettringite formation Processes and problems, Cem. Concr. Comp. 18 [3], 205-215. http://dx.doi.org/10.1016/0958-9465(96)00017-0.

12. Taylor, H.F.W.; Famy, C.; Scrivener, K.L. (2001) Delayed ettringite formation, Cem. Concr. Res. 31 [5], 683-693. http://dx.doi.org/10.1016/S0008-8846(01)00466-5.

13. Pavoine, A.; Divet, L.; Fenouillet, S. (2006) A concrete performance test for delayed ettringite formation: Part I optimisation, Cem. Concr. Res. 36 [12], 2138-2143. http:// dx.doi.org/10.1016/j.cemconres.2006.09.009.

14. Thomas, M. (2003) Occurrences of thaumasite in laboratory and field concrete, Cem. Concr. Comp. 25 [8], 1045-1050. http://dx.doi.org/10.1016/S0958-9465(03)00134-3.

15. Hagelia, P. (2003) Thaumasite and secondary calcite in some Norwegian concretes, Cem. Concr. Comp. 25 [8], 1131-1140. http://dx.doi.org/10.1016/S0958-9465(03)00143-4.

16. Freyburg, E. (2003) Field experiences in concrete deterioration by thaumasite formation: possibilities and problems in thaumasite analysis, Cem. Concr. Comp. 25 [8], 1105-1110. http://dx.doi.org/10.1016/S0958-9465(03)00135-5.

17. Sahu, S.; Badger, S.; Thaulow, N. (2002) Evidence of thaumasite formation in Southern California concrete, Cem. Concr. Comp. 24, 379-384. http://dx.doi.org/10.1016/ S0958-9465(01)00090-7.

18. Crammond, N. (2002) The occurrence of thaumasite in modern construction - a review, Cem. Concr. Comp. 24 [3-4], 393-402. http://dx.doi.org/10.1016/S0958-9465(01) 00092-0.

19. Rodrigues, A.; Duchesne, J.; Fournier, B.; Durand, B.; Rivard, P.; Shehata, M. (2012) Mineralogical and chemical assessment of concrete damaged by the oxidation of sulfidebearing aggregates: Importance of thaumasite formation on reaction mechanisms, Cem. Concr. Res. 42 [10], 1336-1347. http://dx.doi.org/10.1016/j.cemconres.2012.06.008.

20. Mingyu, H.; Fumei, L.; Mingshu, T. (2006) The thaumasite form of sulfate attack in concrete of Yongan Dam, Cem. Concr. Res. 36 [10], 2006-2008. http://dx.doi.org/10.1016/j. cemconres.2006.04.005.

21. Ma, B.; Gao, X.; Byars, E.A.; Zhou, Q. (2006) Thaumasite formation in a tunnel of Bapanxia Dam in Western China, Cem. Concr. Res. 36 [4], 716-722. http://dx.doi. org/10.1016/j.cemconres.2005.10.011.

22. Crammond, N. (2003) The thaumasite form of sulfate attack in the UK, Cem. Concr. Comp. 25 [8], 809-818. http://dx.doi.org/10.1016/S0958-9465(03)00106-9.
23. The_UK_Government_Thaumasite_Expert_Group (1999) The thaumasite form of sulfate attack: Risks, diagnosis, remedial works and guidance on new construction, in Report of the Thaumasite Expert Group, Department of the Environment, Transport and the Regions: London.

24. Brueckner, R. (2008) Accelerating the thaumasite form of sulfate attack and an investigation of its effects on skin friction, in Civil Engineering. University of Birmingham: Birmingham.

25. Aguado, A.; Campos, A.; Chinchón-Payá, S.; López, C.M.; Pardo, F. (2011) Estudio del comportamiento de la presa de Mequinenza. UPC: Barcelona. 254.

26. Buil, J.; Río, F.; Campos, A.; López, C.M.; Aguado, A. (2012) Numerical analysis of Mequinenza Dam, in 24eme Congres des Grands Barrages. Commission Intern. des Grands Barrages: Kyoto. 12.

27. Navarro, J.; Van_Der_Hurk, A. (1992) Mapa Geológico de Espa-a 1:50.000, hoja ${ }^{\circ} 415$ (Mequinenza). IGME, Madrid.

28. Mata-Perelló, J.M. (2009) Recorrido a través del patrimonio geológico y minero de los municipios de Mequinenza/ Mequinensa y Fayón/ Faió (cuenca lignitífera de Mequinenza, Bajo Cinca/Baix Cinca, Bajo Aragón de Caspe/ Baix Aragó de Casp), Revista de Geología serie B 231.

29. Baquer, E.; Caus, E.; Desir, G.; Navarro, J.M.; Panillo, D.; Pocoví, A. (1999) Pinceladas de Geología, Cuadernos de Estudios Caspolinos 24, 23-44.

30. Olivella, À. (2000) Estudi del sofre en combustibles fòssils, in Universitat Politècnica de Catalunya. Departament d'Enginyeria Minera i Recursos Naturals. UPC: Barcelona.

31. White, C.M.; Collins, L.W.; Veloski, G.A.; Irdi, G.A.; Rothenberger, K.S.; Gray, R.J.; LaCount, R.B.; Kasrai, M.; Bancroft, G.M. (1994) A study of Mequinenza lignite, Energy \& Fuels 8 [1], 155-171. http://dx.doi.org/10.1021/ ef00043a027.

32. Fulloa, J. (2007) La cuenca lignitífera de Mequinenza: Características del mineral e implicaciones económicas, in I Encuentro de Jóvenes Investigadores en Historia Contemporánea de la AHC, IFC, Editor: Zaragoza. 11.

33. Rietveld, H. (1969) A profile refinement method for nuclear and magnetic structures, Journal of Applied Crystallography 2 [2], 65-71. http://dx.doi.org/10.1107/ S0021889869006558.

34. Young, R.A. (1995) The Rietveld Method. Monographs on Crystallography: Oxford University Press.

35. Bish, D.L.; Howard, S.A. (1988) Quantitative phase analysis using the Rietveld method, Journal of Applied Crystallography 21 [2], 86-91. http://dx.doi.org/10.1107/ S0021889887009415.

36. Poole, A.B.; Thomas, A. (1975) A Staining Technique for the Identification of Sulphates in Aggregates and Concrete, Mineralogical Magazine 40, 315-316. http://dx.doi.org/ 10.1180/minmag. 1975.040.311.15

37. Rodríguez-Carvajal, J. (1990) FULLPROF: A Program for Rietveld Refinement and Pattern Matching Analysis, in Abstracts of the Satellite Meeting on Powder Diffraction of the XV Congress of the IUCr: Toulouse (France). 127.

38. Barnett, S.J.; Adam, C.D.; Jackson, A.R.W. (2000) Solid solutions between ettringite, $\mathrm{Ca}_{6} \mathrm{Al}_{2}\left(\mathrm{SO}_{4}\right)_{3}(\mathrm{OH})_{12} \cdot 26 \mathrm{H}_{2} \mathrm{O}$, and thaumasite, $\mathrm{Ca}_{3} \mathrm{SiSO}_{4} \mathrm{CO}_{3}(\mathrm{OH})_{6} \cdot 12 \mathrm{H}_{2} \mathrm{O}$, Journal of Materials Science 35 [16], 4109-4114. http://dx.doi.org/ 10.1023/A:1004898623884

39. Barnett, S.J.; Macphee, D.E.; Crammond, N.J. (2003) Extent of immiscibility in the ettringite-thaumasite system, Cem. Concr. Comp. 25 [8] 851-855. http://dx.doi.org/ 10.1016/S0958-9465(03)00116-1. 